\title{
Circumvallate Placenta
}

National Cancer Institute

\section{Source}

National Cancer Institute. Circumvallate Placenta. NCI Thesaurus. Code C117347.

A placenta characterized by fetal membranes that are folded along all or part of the disc perimeter. The amnion may or may not be included in the folded tissue. 